\title{
KAJI BANDING KUALITAS SPERMATOZOA SAPI SIMMENTAL, LIMOUSIN, DAN FRIESIAN HOLSTEIN TERHADAP PROSES PEMBEKUAN
}

\section{FREEZABILITY COMPARISON OF SIMMENTAL, LIMOUSIN AND FRIESIAN HOLSTEIN SPERMATOZOA}

\author{
Komariah*, Iis Arifiantini, dan Fachri Widya Nugraha \\ Departemen Ilmu Produksi dan Teknologi Peternakan, Fakultas Peternakan, Institut Pertanian Bogor, Jl. Rasamala \\ Kampus Dramaga, Bogor, 16680
}

\section{INTISARI}

Penelitian ini bertujuan untuk mempelajari dan membandingkan kualitas spermatozoa beku sapi Simmental, Limousin, dan Friesian Holstein (FH) di Balai Inseminasi Buatan Lembang (BIB), Bandung, Jawa Barat. Jumlah sapi yang digunakan pada penelitian ini adalah 24 ekor sapi jantan yang terdiri atas 8 Simmental, 8 Limousin, dan 8 FH berumur 4 tahun dengan kisaran bobot badan $800-900 \mathrm{~kg}$. Penelitian menggunakan data sekunder dan primer BIB Lembang bulan November sampai Desember 2010. Data sekunder yang diambil adalah data motilitas spermatozoa segar meliputi, before freezing (BF), post thawing motility (PTM), longivitas dan data primer yaitu nilai recovery rate. Hasil yang diperoleh dari penelitian adalah motilitas spermatozoa segar dan before freezing sapi Simmental lebih tinggi $(\mathrm{P}<0,05)$ dibandingkan sapi Limousin dan FH, sedangkan hasil PTM, longivitas, dan recovery rate tidak berbeda nyata pada ketiga bangsa tersebut.

(Kata kunci: Freezability, Spermatozoa, Simmental, Limousin, Friesian Holstein)

\begin{abstract}
The purpose of this research was to study and to compare the freezability of Simmental, Limousin and Friesian Holstein (FH) frozen spermatozoa at Lembang Artificial Insemination Centre, Bandung, West Java. Twenty four bulls were used in this study consist of 8 Simmental, 8 Limousin and 8 Friesian Holstein (FH), age 4 years old with average of weight of 800-900 kg. Primer and secondary data were collected from the period of November to December 2010. The secondary data was collected from raw spermatozoa, before freezing, post thawing motility (PTM), longivity and primer data was the value of recovery rate. The results showed that spermatozoa motility and before freezing spermatozoa from Simmental higher $(P<0.05)$ than Limousin and FH bull, howefer there were no difference between post thawing motility, longevity and value of recovery rate among three breeds.
\end{abstract}

(Keywords: Freezability, Spermatozoa, Simmental, Limousin, Friesian Holstein)

\section{Pendahuluan}

Konsumsi pangan secara global akan meningkat 40-50\% pada tahun 2050 (Food and Agriculture Organization, 2010). Peningkatan konsumsi pangan khususnya akan lebih cepat di negara-negara berkembang, termasuk Indonesia. Menurut informasi Badan Pusat Statistik (2010) pertambahan penduduk Indonesia rata-rata 1,25\% per tahun, jumlah penduduk yang tercatat di Badan Pusat Statistik tahun 2000 yaitu 206.264.595 jiwa dan tahun 2010 adalah 237.641.326 jiwa. Pertambahan penduduk ini harus diimbangi ketersediaan pangan yang cukup diantaranya bersumber dari protein hewani berupa susu dan daging. Sumber susu yang saat ini tersedia sebagian besar disuplai oleh sapi perah jenis Friesian Holstein (FH) dan

\footnotetext{
*Korespondensi (corresponding author):

Telp. +62 8179910166

Email: komariah_purjati@yahoo.com
}

sumber daging banyak disuplai oleh bangsa sapi Simmental dan Limousin. Saat ini ketiga breed tersebut diproduksi spermatozoa bekunya oleh beberapa balai inseminasi buatan (BIB), diantaranya oleh BIB Lembang.

Balai Inseminasi Buatan Lembang bergerak dalam usaha memproduksi spermatozoa beku bibit unggul. Spermatozoa beku memiliki keunggulan yaitu dapat digunakan dalam jangka waktu yang lama, namun memiliki kelemahan yaitu kualitas spermatozoa dapat menurun setelah spermatozoa diencerkan dikarenakan selama proses pembekuan, spermatozoa melewati berbagai suhu ekstrim yang dapat menurunkan kualitas spermatozoa (Garner dan Hafez, 2000).

Bangsa sapi akan mempengaruhi kualitas spermatozoa beku yang dihasilkan. Hal ini terbukti dari perbedaan nilai recovery rate (Hafez, 2000). Keberhasilan IB juga ditentukan oleh kualitas dan kuantitas spermatozoa beku pejantan yang dipengaruhi oleh karakteristik spermatozoa segarnya 
yang dapat diuji secara makroskopis dan mikroskopis.

Tingkat keberhasilan IB yang tinggi diharapkan dapat meningkatkan efisiensi produktivitas, yang ditandai dengan meningkatnya populasi ternak sapi di Indonesia sehingga dapat memenuhi permintaan kebutuhan protein hewani di Indonesia.

Penelitian ini bertujuan untuk mempelajari dan membandingkan penurunan kualitas spermatozoa beku sapi Simmental, Limousin, dan FH di Balai Inseminasi Buatan Lembang, Bandung, Jawa Barat.

\section{Materi dan Metode}

Penelitian dilakukan di Laboratorium Balai Inseminasi Buatan (BIB) Lembang, Bandung, Jawa Barat. Data penelitian yang digunakan adalah data sekunder produksi spermatozoa NovemberDesember 2010 dari 8 ekor sapi Limousin, Simmental, dan FH berumur sekitar 4 tahun, dengan bobot badan masing-masing berkisar antara $850 \pm 40,38 \mathrm{~kg}, 900 \pm 50,85 \mathrm{~kg}$, dan $800 \pm 43,4 \mathrm{~kg}$.

Teknik koleksi dan evaluasi spermatozoa segar dilakukan oleh teknisi sesuai standar BIB Lembang. Pemeriksaan kualitas spermatozoa segar dilakukan secara makroskopis dan mikroskopis. Evaluasi secara makroskopis meliputi warna, volume, konsistensi, dan $\mathrm{pH}$. Selanjutnya dilakukan pengamatan mikroskopis terhadap gerakan massa, motilitas dan konsentrasi serta before freezing, post thawing motility, dan longivitas. Analisis data primer nilai recovery rate dihitung berdasarkan rumus berikut.

Perhitungan recovery rate:

$\mathrm{RR}=\frac{\text { Motilitas spermatozoa setelah thawing }}{\text { Motilitas spermatozoa segar }} \times 100 \%$

Pengamatan gerakan masa menggunakan mikroskop elektrik dengan pembesaran $4 \times 10$; yang layak diproses adalah gerakan masa ++ dan motilitas minimal 70\%. Pemeriksaan konsentrasi menggunakan spektofotometer yang sudah distandarisasi dengan $\mathrm{NaCl} 2 \%$. Proses pembekuan spermatozoa menggunakan $\mathrm{N}_{2}$ cair di dalam storage container dengan suhu $-110^{\circ} \mathrm{C}$ sampai dengan $-120^{\circ} \mathrm{C}$ selama 5 menit. Setelah itu dimasukkan dalam goblet sesuai kapasitas kemudian disimpan dalam container yang terendam $\mathrm{N}_{2}$ cair dengan suhu $-196^{\circ} \mathrm{C}$. Kapasitas storage container adalah 150.000-350.000 dosis mini straw dalam rendaman 210-800 liter $\mathrm{N}_{2}$ cair; untuk menjaga penguapan, setiap hari ditambahkan 30 liter $\mathrm{N}_{2}$ cair dalam setiap container sampai siap digunakan.

\section{Pengujian before freezing}

Straw dihangatkan dan dilakukan equilibration dalam cool top, kemudian dilakukan pengamatan motilitas spermatozoa di bawah mikroskop dengan pembesaran $400 \mathrm{x}$.

\section{Pengujian post thawing motility}

Sperma beku diencerkan (thawing), sampel diambil untuk dilakukan pengamatan spermatozoa motil progresif di bawah mikroskop dengan pembesaran $10 x 40$. Persentase spermatozoa motil progresif diamati dari lima lapang pandang antar 0$100 \%$ dengan kriteria $0-4$ yaitu:

0 : tidak ada gerakan individu spermatozoa

$1:$ gerakan individu spermatozoa lambat

2 : gerakan individu spermatozoa sedang

3 : gerakan individu spermatozoa cepat

4 : gerakan individu spermatozoa sangat cepat

Bahan pengencer yang digunakan adalah part $A$ : $950 \mathrm{cc}$ buffer antibiotik ditambah $50 \mathrm{cc}$ kuning telur dalam $1000 \mathrm{cc}$ pengencer; part B : $770 \mathrm{cc}$ buffer antibiotik ditambah $160 \mathrm{cc}$ gliserol, $50 \mathrm{cc}$ kuning telur dan $20 \mathrm{~g}$ glukosa dalam $1000 \mathrm{cc}$ pengencer. Spermatozoa yang akan diproses dicampur dengan pengencer part $A$, disimpan dalam incubator dengan suhu $37^{\circ} \mathrm{C}$ selama 35 menit dan diberi label kemudian disimpan dalam cool top dengan suhu $4^{\circ} \mathrm{C}$ selama 55 menit ditambahkan pengencer part $B$ sebanyak 4 kali setiap 15 menit di dalam cool top (proses glyserolisasi). Pencampuran ini diikuti dengan proses filling dan sealing ke dalam straw yang telah diberi label setelah 2,5 jam pencampuran part $B$ selesai. Buffer antibiotik 1000 cc terdiri dari : $100 \mathrm{~g}$ susu skim, $960 \mathrm{cc}$ aquabidest, antibiotik dengan perbandingan 100:1; antibiotik yang digunakan 3 juta IU penicillin dan $3 \mathrm{~g}$ streptomicyn ditambah aquabidest hingga volumenya $30 \mathrm{cc}$.

\section{Longivitas (water incubator test)}

Setelah 4 jam dalam dry incubator, sampel diambil secara homogen kemudian dilakukan pengamatan terhadap gerakan individu dan motilitas spermatozoa di bawah mikroskop dengan pembesaran 10x10. Standar minimal adalah motilitas 5$10 \%$ dengan gerakan individu lambat (1).

\section{Analisis data}

Rancangan percobaan yang digunakan pada penelitian ini adalah Rancangan Acak Lengkap (RAL) menurut Steel dan Torrie (1991) dengan perlakuan tiga bangsa sapi yang berbeda dan empat kali ulangan pada masing-masing bangsa sapi.

Model matematisnya adalah:

$$
\mathrm{Yij}=\mu+\mathrm{P}_{\mathrm{i}}+\mathcal{E}_{\mathrm{ij}}
$$


Keterangan:

Yij = nilai motilitas spermatozoa dari sapi ke-i yang mendapat nilai perlakuan ke-j

$\mu \quad=$ nilai rata-rata umum

$\mathrm{P}_{\mathrm{i}} \quad=$ pengaruh perlakuan ke-i

$\varepsilon_{\mathrm{ij}}=$ pengaruh galat percobaan pada sapi ke-i yang mendapat perlakuan ke-j

Seluruh data yang diperoleh diolah menggunakan software Statistic 8, data disajikan dalam bentuk rataan dan simpangan baku. Pengaruh perlakuan yang nyata pada penelitian ini dilanjutkan dengan uji lanjut yaitu uji Tukey.

\section{Hasil dan Pembahasan}

Hasil penelitian pada Tabel 1 menunjukkan kualitas sperma secara makroskopis cukup bagus, dengan volume sperma berkisar antara 6-8 $\mathrm{ml}$, hasil yang diperoleh sesuai dengan pendapat Garner dan Hafez (2000), volume sperma sapi setiap satu kali ejakulasi berkisar antara 5-8 ml, sehingga hasil volume sperma yang didapatkan masih dalam kisaran normal.

Warna sperma yang diperoleh dari sapi Limmousin, Simmental, dan FH putih susu sampai dengan krem. Menurut Garner dan Hafez (2000) ejakulat normal sperma sapi berwarna krem sampai putih susu, sperma dengan konsentrasi yang rendah akan terlihat bening dan tembus cahaya.

Konsistensi atau derajat kekentalan sperma sapi dari ketiga bangsa adalah konsistensi sedang, sperma sapi yang normal memiliki konsistensi dari sedang sampai kental (Feradis, 2010). Derajat keasaman $(\mathrm{pH})$ sperma ketiga bangsa sapi adalah
6,49-6,54. Nilai ini termasuk normal karena kisaran pH sperma sapi adalah 6,4-7,8 (Garner dan Hafez, 2000).

Secara makroskopis, ketiga bangsa sapi menunjukkan gerakan masa spermatozoa yang normal yaitu positif 2 dengan skala $0-3$. Nilai ini termasuk cukup baik. Menurut Campbel et al. (2003a) pada spermatozoa sapi kisaran normal gerakan massa adalah ++ sampai dengan +++ .

Nilai motilitas spermatozoa segar Simmental adalah $80,16 \pm 7,80 \%$, nilai ini lebih tinggi $(\mathrm{P}<0,05)$ dibandingkan dengan Limousin, dan FH masing-

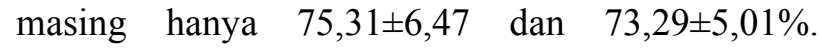
Meskipun demikian nilai motilitas spermatozoa dari ketiga breed tersebut termasuk normal, karena menurut Bearden et al. (2004) nilai motilitas spermatozoa sapi berkisar antara 70 sampai $80 \%$. Banyak faktor yang mempengaruhi perbedaan nilai motilitas spermatozoa diantaranya umur, bangsa, kematangan spermatozoa, dan kualitas plasma spermatozoa (Garner dan Hafez, 2000).

Konsentrasi adalah jumlah sel spermatozoa per milliliter sperma. Hasil pengamatan menunjukkan konsentrasi spermatozoa segar yang diperoleh dari ketiga bangsa sapi tersebut adalah 1561,87 sampai dengan 1899,3 juta/mL. Konsentrasi spermatozoa ketiga sapi tersebut sangat tinggi, mengingat bahwa konsentrasi spermatozoa pada sapi jantan dewasa berkisar antara 800-1200 juta/ml spermatozoa (Campbel et al., 2003b). Hal ini dapat dipahami, mengingat sapi-sapi yang digunakan adalah milik Balai IB yang merupakan hasil seleksi yang sudah teruji kualitasnya dan dipelihara dengan manajemen yang baik.

Tabel 1. Rataan karakteristik sperma sapi Limousin, Simmental, dan Friesian Holstein (the average of spermatozoa characteristic of Limousin, Simmental and Friesian Holstein)

\begin{tabular}{|c|c|c|c|}
\hline \multirow{2}{*}{ Karakteristik (characteristic) } & \multicolumn{3}{|c|}{ Bangsa sapi (breed) } \\
\hline & Limousin & Simmental & $\mathrm{FH}$ \\
\hline \multicolumn{4}{|l|}{ Makroskopis (macroscopic) } \\
\hline Warna (color) & $\begin{array}{l}\text { Putih susu (white } \\
\text { milk) }\end{array}$ & $\begin{array}{l}\text { Putih susu (white } \\
\text { milk) }\end{array}$ & $\begin{array}{l}\text { Putih susu (white } \\
\text { milk) }\end{array}$ \\
\hline Volume (ml) (volume) & $7,1 \pm 2,4$ & $6,8 \pm 1,1$ & $8,8 \pm 2,3$ \\
\hline Konsistensi (consistency) & Sedang (medium) & Sedang (medium) & Sedang (medium) \\
\hline $\mathrm{pH}$ & $6,50 \pm 0,2$ & $6,51 \pm 0,2$ & $6,9 \pm 0,1$ \\
\hline \multicolumn{4}{|l|}{ Mikroskopis (microscopic) } \\
\hline Gerakan massa (mobility) & ++ & ++ & ++ \\
\hline Motilitas (\%) (motility (\%)) & $75,3 \pm 6,4$ & $80,16 \pm 7,8$ & $73,2 \pm 5,01$ \\
\hline $\begin{array}{l}\text { Konsentrasi (jt/ml) (concentration } \\
(\text { million } / \mathrm{ml}))\end{array}$ & $1721,2 \pm 332,60$ & $1899,3 \pm 254,8$ & $1561,8 \pm 312,5$ \\
\hline
\end{tabular}


Menurut Gordon (2004) warna, jumlah, volume, konsentrasi, konsistensi, gerakan massa, $\mathrm{pH}$, dan motilitas spermatozoa segar dari seekor pejantan sangat bervariasi. Hal ini dipengaruhi oleh banyak faktor antara lain kondisi masing-masing individu, seperti kualitas organ reproduksi, umur ternak, kondisi manajemen peternakan, jenis pakan yang diberikan, dan bangsa sapi yang digunakan. Hasil pemeriksaan menunjukan bahwa sperma yang diperoleh selama penelitian dari sapi Limousin, Simmental, dan FH berada pada kisaran normal dan dapat dikategorikan sperma yang berkualitas baik sehingga dapat diproses lebih lanjut menjadi sperma beku.

\section{Motilitas spermatozoa}

Persentase motilitas spermatozoa minimal $80 \%$, before freezing minimal $60 \%$, post thawing motility minimal $40 \%$, recovery rate minimal $50 \%$, dan longivitas minimal $10 \%$ untuk dapat diinseminasikan (Hafez, 2000).

Berdasarkan hasil penelitian menunjukkan nilai motilitas spermatozoa setelah equilibration (before freezing) pada sapi Simmental lebih tinggi yaitu $65,12 \pm 5,53 \%$ dibandingkan sapi Limousin dan FH dengan nilai motilitas spermatozoa masingmasing adalah $63,44 \pm 3,22$ dan $63,12 \pm 3,53 \%$ (Tabel 2).

Post thawing motility yaitu pengujian motilitas spermatozoa setelah dibekukan dengan cara melakukan thawing sperma beku pada air dengan temperatur $37^{\circ} \mathrm{C}$ selama 30 detik. Motilitas spermatozoa PTM pada ketiga bangsa sapi tersebut tidak menunjukkan perbedaan dengan nilai post thawing motility masing-masing adalah Limousin $(44,06 \pm 3,46)$, Simmental $(44,69 \pm 2,98)$, dan FH $(42,97 \pm 2,80 \%)$.

Recovery rate adalah kemampuan pemulihan spermatozoa setelah pembekuan dengan membandingkan motilitas spermatozoa setelah thawing dengan motilitas spermatozoa segar (Hafez, 2000). Hasil penelitian ini juga tidak menunjukkan perbedaan dengan nilai RR untuk masing-masing sapi Limousin, Simmental, dan FH adalah $58,87 \pm 6,37 ; 56,27 \pm 7,08$ dan $58,87 \pm 5,31 \%$.

Longivitas spermatozoa adalah kemampuan spermatozoa bertahan pada temperatur tertentu (Hafez, 2000). Pengujian longivitas di BIB Lembang menggunakan teknik water incubator test. Hasil penelitian juga tidak menunjukkan perbedaan longivitas antara spermatozoa sapi Limousin, Simmental, dan FH dengan nilai masing-masing $13,91 \pm 5,34 ; 13,91 \pm 4,35$ dan $14,06 \pm 5,60 \%$.

Hafez (2000), menyatakan bahwa spermatozoa yang dibekukan akan mengalami kerusakan sekitar $40 \%$ dan untuk menghasilkan spermatozoa beku yang berkualitas tinggi, baik dan terjamin kualitasnya untuk spermatozoa yang akan diinseminasikan, maka dibutuhkan bahan pengencer spermatozoa yang mampu mempertahankan kualitas spermatozoa selama proses pembekuan, maupun pada saat pengenceran.

Hasil dari analisis statistik sapi Simmental memiliki nilai motilitas spermatozoa dan before freezing yang lebih tinggi daripada sapi Limmousin dan FH. Hal ini menunjukkan bahwa bangsa yang berbeda mempengaruhi kualitas spermatozoa yang dihasilkan. Hasil yang didapat sesuai dengan pernyataan Garner dan Hafez (2000) yang menyatakan bahwa perbedaan antar bangsa mempengaruhi kualitas spermatozoa yang dihasilkan dan Srianto et al. (2009) menyebutkan bahwa jumlah volume, konsentrasi, dan motilitas spermatozoa yang dihasilkan oleh tiap-tiap sapi pejantan yang digunakan untuk proses produksi spermatozoa beku berbeda. Perbedaan pada ketiga bangsa tersebut bisa saja disebabkan oleh genetik sapi.

Motilitas spermatozoa post thawing motility, recovery rate dan longivitas pada ketiga bangsa sapi tersebut tidak menunjukkan perbedaan yang

Tabel 2. Nilai motilitas spermatozoa pada berbagai tahapan pembekuan (the spermatozoa motility of freezibilities)

\begin{tabular}{|c|c|c|c|}
\hline \multirow{3}{*}{ Peubah (variable) } & \multicolumn{3}{|c|}{ Bangsa sapi (breeds) } \\
\hline & Limousin & Simmental & Friesian Holstein \\
\hline & \multicolumn{3}{|c|}{ - } \\
\hline Fresh sperm & $75,31 \pm 6,47^{b}$ & $80,16 \pm 7,80^{\mathrm{a}}$ & $73,29 \pm 5,01^{\mathrm{b}}$ \\
\hline Before freezing & $63,44 \pm 3,22^{\mathrm{b}}$ & $65,12 \pm 5,53^{\mathrm{a}}$ & $63,12 \pm 3,53^{\mathrm{b}}$ \\
\hline Post thawing motility & $44,06 \pm 3,46$ & $44,69 \pm 2,98$ & $42,97 \pm 2,80$ \\
\hline Recovery rate & $58,87 \pm 6,37$ & $56,27 \pm 7,08$ & $58,87 \pm 5,31$ \\
\hline Longivity & $13,91 \pm 5,34$ & $13,91 \pm 4,35$ & $14,06 \pm 5,60$ \\
\hline
\end{tabular}

${ }^{\mathrm{a}, \mathrm{b}}$ Superskrip yang berbeda pada baris yang sama menunjukkan perbedaan nyata $(\mathrm{P}<0,05)$ (different superscripts at the same row indicate significant differences $(P<0.05))$. 
nyata. Hal ini diduga karena jenis pengencer yang digunakan dan pemberian pakan yang diberikan sama untuk ketiga bangsa tersebut. Hasil yang didapat dari penelitian ini berbeda dari hasil penelitian Arifiantini et al. (2004) motilitas spermatozoa post thawing motility pada sapi $\mathrm{FH}$ dengan menggunakan pengencer kacang kedelai $(\mathrm{KK})$, tris sukrosa (TS) dan tris motilitas spermatozoa $50,20 \pm 7,07 ; 46,04 \pm 3,54$ dan $43,02 \pm 7,68 \%$; sedangkan motilitas spermatozoa fruktosa (TF) masing-masing menunjukkan nilai recovery rate $69,56 \pm 11,32 ; \quad 63,48 \pm 9,25$ dan $59,40 \pm 11,24 \%$. Penelitian Arifiantini et al. (2005) mengujicobakan lama waktu longivitas dari 0 jam sampai dengan 9 jam pada suhu $37^{\circ} \mathrm{C}$. Motilitas spermatozoa longivitas pada pengamatan jam ke-4 masing-masing menunjukkan nilai motilitas yaitu $20,81 \pm 17,68 ; \quad 10,09 \pm 7,07 ; \quad$ dan $10,61 \pm 8,49$, sedangkan pada pengamatan jam ke-5 masingmasing menunjukkan nilai motilitas spermatozoa $17,68 \pm 15,57 ; 5,47 \pm 3,54$ dan $3,53 \pm 3,11$. Menurut Paulenz et al. (2002) jenis pengencer spermatozoa sangat bervariasi dan masing-masing memiliki keistimewaan.

\section{Kesimpulan}

Motilitas spermatozoa segar dan before freezing sapi Simmental lebih tinggi daripada sapi Limmousin dan FH, dan tidak ada perbedaan post thawing motility, recovery rate, dan longivitas spermatozoa pada ketiga bangsa tersebut.

\section{Daftar Pustaka}

Arifiantini, I., T. L. Yusuf, dan D. Yanti. 2004. Kaji banding penurunan kualitas spermatozoa beku sapi Friesian Holstein menggunakan pengencer dari berbagai Balai Inseminasi Buatan di Indonesia. Anim. Prod. 7: 168-176.

Arifiantini, I., T. L. Yusuf, dan N. Graha. 2005. Longivitas dan recovery rate pasca thawing spermatozoa beku sapi Friesian Holstein menggunakan bahan pengencer yang berbeda. Buletin Peternakan 29: 53-61.

Badan Pusat Statistik. 2010. Statistik Penduduk 2009. Departemen Pertanian. Jakarta.
Bearden J. H., J. W. Fuquay and S. T. Willard. 2004. Artificial insemination. In: Applied Animal Reproduction. $6^{\text {th }}$ ed. Pearson Education, New Jersey.

Campbell, J. R., K. L. Campbell and M. D. Kenealy. 2003a. Anatomy and physiology of reproduction and related technologies in farm mammals. In: Animal Sciences. $4^{\text {th }}$ ed. New York, Mc Graw-Hill.

Campbell, J. R., K. L. Campbell and M. D. Kenealy. 2003b. Artificial insemination. In: Animal Sciences $4^{\text {th }}$ ed. New York, Mc Graw-Hill.

Feradis, M. P. 2010. Bioteknologi Reproduksi Ternak. Alphabeta, Bandung.

Food and Agriculture Organization. 2010. Report statistic of livestock production. Available at http/www.fao.org/corp statistics/en/ Accession date: February 12, 2012.

Garner, D. L. and E. S. E. Hafez. 2000. Spermatozoa and seminal plasma. In: Reproduction in Farm Animals. $7^{\text {th }}$ ed. E. S. E. Hafez and B. Hafez (eds). Lippincot Williams \& Wilkins, Philadelphia.

Gordon, I. 2004. Artificial insemination. In: Reproductive Technologies in Farm Animals. CABI publishing, Wallingford.

Hafez, E. S. E. 2000. Preservation and cryopreservation of gametes and embryos. In: Reproduction in Farm Animals. $7^{\text {th }}$ ed. E. S. E. Hafez and B. Hafez (eds). Lippincot Williams \& Wilkins, Philadelphia.

Paulenz, H., L. Soderquist, R. Perez-Pe and K.A. Berg. 2002. Effect of different extender and storage temperatures on sperm viability of liquid ram spermatozoa. Theriogenology 57: 823-836.

Srianto, P. S. P., Madyawati, dan T. Sardjito. 2009. Kadar hormon dan mineral serum darah sapi pejantan di Balai Inseminasi Buatan Daerah. Laporan Penelitian. Fakultas Kedokteran Hewan, Universitas Airlangga. Surabaya.

Steel, R. G. D. dan Torrie. 1991. Prinsip dan Prosedur Statistika. Terjemahan: B. Sumantri. PT Gramedia Pustaka Utama. Jakarta. 